\title{
Case studies of steel and their welded joint failures caused by liquid metal embrittlement LME
}

\author{
Analiza przypadków \\ pęknięć stalowych złączy spawanych \\ wywołanych obecnością cieczy metalicznej
}

\begin{abstract}
Liquid metal embrittlement (LME) is a phenomenon, where liquid (molten) metal is mostly intergranulary (but not only) penetrated into solid metal and causes its brittle fracture. The LME is usually related to low melting metals (zink, tin , cadmium), which are in the contact with higher molten ones (steels, Ni alloys). Cases of LME as a Cu penetration into pipeline welded joint of $15 \mathrm{G} 2 \mathrm{~S}$ steel ,a hot temperature corrosion in the cement works shell plate made of AISI 310 stainless steel attacted by $\mathrm{Ni}_{3} \mathrm{~S}_{2}\left(\mathrm{Ts}=644^{\circ} \mathrm{C}\right)$ and a vanadium corrosion in the boiler vessel (10CrMo9-10 steel) due to $\mathrm{V}_{2} \mathrm{O}_{5}+\mathrm{Na}_{2} \mathrm{SO}_{4}$ eutecticum $\left(\sim 600^{\circ} \mathrm{C}\right)$ are concerned.
\end{abstract}

Keywords: hot crack, liquid metal embrittlement

\section{Streszczenie}

Kruchość stali wywołana obecnością cieczy metalicznej (ang. LME - liquid metal embrittlement) zachodzi podczas oddziaływania i w konsekwencji penetrowania granic ziaren (stali oraz stopów Ni) niskotopliwych metalami (cu, Zn, Col Sn), w warunkach działania naprężeń rozciągających. W artykule przeanalizowano przypadki LME wynikające $z$ penetrowania Cu złączy spawanych rurociągów ze stali $15 \mathrm{G} 29$ oraz wysokotemperaturowej erozji płyt ze stali $310 \mathrm{wg}$ ALSI wywołanej działaniem $\mathrm{Ni}_{3} \mathrm{~S}_{2}\left(\mathrm{Ts}-644^{\circ} \mathrm{C}\right)$ oraz erozji kotła ze stali $10 \mathrm{CrMo9}-10$ wywołanym oddziaływaniem $\mathrm{w}$ wysokiej temperaturze $\mathrm{V}_{2} \mathrm{O}_{5}+\mathrm{Na}_{2} \mathrm{SO}_{4}$.

Słowa kluczowe: pęknięcie gorące, kruchość, ciecz metaliczna

\section{Introduction}

Liquid metal embrittlement (LME) is a phenomenon, where certain ductile metals show drastic loss in tensile ductility or undergo brittle fracture when occured in the presence of specific liquid metals. Generally, a tensile stress, either externally applied or internally present, is needed to induce embrittlement [1].
Liquid metal embrittlement is caused by a combination of two factors [2]. These are 1) The presence of a specific liquid (molten)metal in contact with the affected component or structure, and 2) An applied or residual tensile stress acting on the affected component or structure while in contact with the liquid metal. When these two conditions occur, the liquid metal is absorbed in the components' grain bound-

Prof. Peter BERNASOVSKÝ Ph.D., Ing. Peter BRZIAK Ph.D., Ing. Ĺuboš Mráz Ph.D. - Welding Research Institute - Industrial Institute of Slovak Republik, Bratislava, Slovakia. 
aries in a manner similar to the capillary action. A liquid-metal filled crack is produced as the boundary between grains absorbs the molten metal and breaks the bond between adjacent grains.

The general rules for the possible occurrence of liquid metal embrittlement are [3]:

- Low mutual solubility between the liquid and solid metals.

- Absence of intermetallic compound formation between the solid-liquid couple.

The hardness and deformation behavior of the solid metal affect its susceptibility to LME. Generally, harder metals are more severely embrittled. Grain size greatly influences LME. Solids with larger grains are more severely embrittled.

The interfacial energy between the solid and liquid metals and the grain boundary energy of the solid metal greatly influence LME. These energies depend upon the chemical composition of the metal couple. Dihedral angle of liquid between grain boundaries is lowest, when an interfacial energy between solid grains is double to an interfacial energy between the solid grain and the liquid.

Some significant examples of embrittling couples include: steel - $\mathrm{Cu}$, stainless steel - Zn, aluminium - Hg.

LME occurs at melting point of liquid metal during heat treatment, hot rolling, brazing, soldering and welding. The welded joints are more susceptible to $L M E$, because of higher hardness, larger grains and notches of stress concentration.

In the literature there are a wide variety of LME couples [4], but all are related to liquid phases of the pure elements. In this contribution besides of $\mathrm{Cu}$ we propose to include among liquids which may cause LME of steels also low melting compounds like $\mathrm{Ni}_{3} \mathrm{~S}_{2}$ and $\mathrm{V}_{2} \mathrm{O}_{5}+\mathrm{Na}_{2} \mathrm{So}_{4}$.

\section{Gas pipeline failures}

Slovakia belongs to the countries with the densest network of high pressure transmission gas pipelines. Four large diameter lines are already passing through its territory, whereas the 5th line is being completed at present. The oldest gas pipelines are in service for almost four decades and though they are inspected periodically, from time to time some failures of pipelines occur.

This case occurred on the 1st international gas pipeline which was built in 1965 . This line, made of an old Russian steel 15 G2S (type L380N) low alloyed with Si (see Table I) is the most problematic one at present. In this line low ductility and toughness of steel have met together with the poor workmanship.

In this case (spirally welded pipe OD 720x8 mm) $1.8 \mathrm{~m}$ long crack was running along the spiral weld (Fig. 1). The initiation point was in the place where the spiral weld meets the tie strip weld. The spiral weld which exhibits very high misalignment of both linear and opposite runs is shown in Fig. 2. The crack was initiated by LME (liquid metal embrittlement) of remelted copper during repair weld-

Table I. Chemical composition [wt \%]

Tablica I. Skład chemiczny [wag.\%]

\begin{tabular}{|c|c|c|c|c|c|c|c|c|}
\hline C & $\mathrm{Mn}$ & $\mathrm{Si}$ & $\mathrm{P}$ & $S$ & $\mathrm{Cr}$ & $\mathrm{Ni}$ & $\mathrm{Cu}$ & $\mathrm{Ti}$ \\
\hline $0,14-0,15$ & $1,37-1,45$ & $1,07-1,08$ & 0,014 & 0,029 & 0,06 & 0,05 & 0,08 & 0,032 \\
\hline \multicolumn{2}{|c|}{$\mathrm{Re}, \mathrm{MPa}$} & \multicolumn{2}{|c|}{$\mathrm{Rm}, \mathrm{MPa}$} & $A 5, \%$ & \multicolumn{2}{|c|}{ ChV FATT, 50 J.cm ${ }^{2}$} & \multicolumn{2}{|c|}{ Upper shelf } \\
\hline \multicolumn{2}{|c|}{$387-404$} & \multicolumn{2}{|c|}{$591-612$} & $22-27$ & \multicolumn{2}{|c|}{$+14^{\circ} \mathrm{C}$} & \multicolumn{2}{|c|}{$55 \mathrm{j} \cdot \mathrm{cm}^{-2}$} \\
\hline \multicolumn{9}{|c|}{$\begin{array}{l}\text { Fig. 1. A crack along the spirally weld joint } \\
\text { Rys. } 1 . \text { Pęknięcie wzdłuż spoiny spiralnej rury }\end{array}$} \\
\hline $\begin{array}{l}\text { Fig. 2a. Linea } \\
\text { Rys. 2a. Mik } \\
\text { - niska jakos }\end{array}$ & $\begin{array}{l}\text { pposite runs } \\
\text { tura złącza } \\
\text { nania złącz }\end{array}$ & $\begin{array}{l}\text { nment }- \text { po } \\
\text { go } z \text { wyraź } \\
\text { nego }\end{array}$ & przesad & iem rur & \multicolumn{4}{|c|}{$\begin{array}{l}\text { Fig. 2b. Liquid metal embrittlement by } \mathrm{Cu} \text { in the HAZ } \\
\text { of repair weld. EDX (wt\%):Cu-81,29; Fe-17,50 and Si-1,21 } \\
\text { Rys. 2b. Kruchość wywołana ciekłą miedzią w SWC } \\
\text { naprawianego złącza. EDX (wag.\%): Cu-81,29; Fe-17,50 } \\
\text { oraz Si-1,21 }\end{array}$} \\
\hline
\end{tabular}


ing (Fig. 3). Cu came from abrading of $\mathrm{Cu}$ electric contact rods which were applied at manufacturing of spiral welds at that time [5].

\section{Cement works}

Shortly after combustion of new wastes (pneumatic tyres, plastics) the shell plates of the cement furnace were expressively attacked by hot temperature corrosion [6]. The steel AISI 310 (1.4841 by EN) was concerned (Table II).

Table II. Chemical composition of AISI 310 steel [wt\%]

Tablica II. Skład chemiczny stali AISI 310 [mas.\%]

\begin{tabular}{|c|c|c|c|c|c|c|c|}
\hline & C & Mn & Si & P & S & Cr & Ni \\
\hline $\begin{array}{c}\text { Atest } \\
\text { VÚZ }\end{array}$ & 0,058 & 0,99 & 0,58 & 0,024 & 0,014 & 23,94 & 19,45 \\
\hline $\begin{array}{c}\text { A I S I } \\
310\end{array}$ & $\begin{array}{r}\text { ax. } \\
0,20\end{array}$ & $\begin{array}{r}\text { ax. } \\
1,50\end{array}$ & $\begin{array}{r}\text { ax. } \\
1,0\end{array}$ & $\begin{array}{r}\text { ax. } \\
0,045\end{array}$ & $\begin{array}{r}\text { ax. } \\
0,030\end{array}$ & $\begin{array}{r}4 \\
26\end{array}$ & $\begin{array}{r}9 \\
22\end{array}$ \\
\hline
\end{tabular}

An original wall thickness of $4 \mathrm{~mm}$ was reduced almost to $0,4 \mathrm{~mm}$ (Fig. 3).

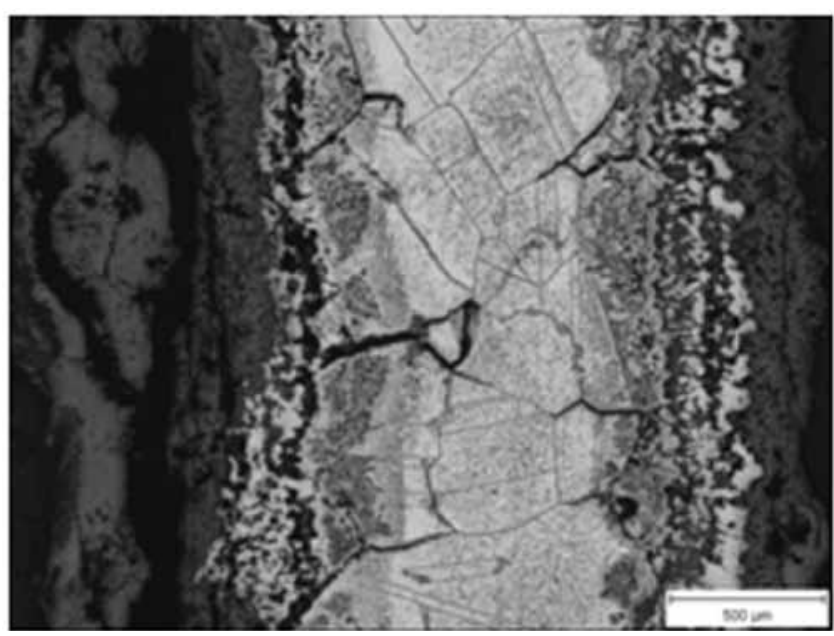

Fig. 3. Wall thickness reduction

Rys. 3. Redukcja grubości ściany na skutek erozji

Grain coarsening of the plate surface (dST=max. $1000 \mathrm{\eta m}$ ) and grain boundary liquation are visible in Fig. 4. A scale thickness reached almost $900 \mu \mathrm{m}$. An EDX microanalysis of the corrosion products showed very high content of $S$ and $P$ (Fig. 5). Both are present like compounds of the nickel sulphide and the iron phosphide.
The AISI 310 is a heat-resisting steel up to $1100{ }^{\circ} \mathrm{C}$ (tolerance loss of thickness is $2 \mathrm{~mm} / 104$ hours), but the steel is not suitable for the reduction gas medium, which contains $S$, where its range of application is reduce down to $644{ }^{\circ} \mathrm{C}$, what is a solidus temperature of $\mathrm{Ni}_{3} \mathrm{~S}_{2}$ (LME attack).

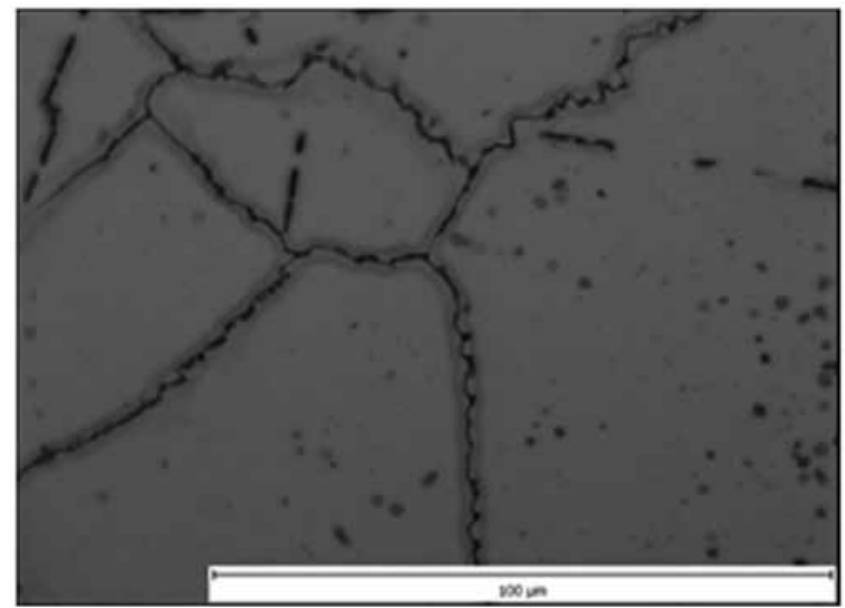

Fig. 4. High temperature attack of AISI 310 steel

Rys. 4. Wysokotemperaturowa degradacja stali $310 \mathrm{wg}$ AISI

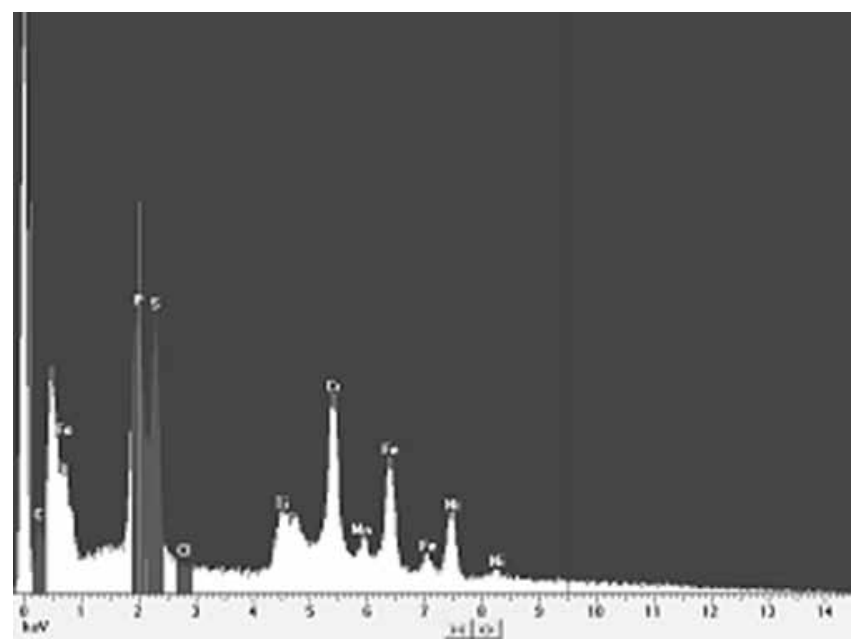

Fig. 5. EDX microanalysis of corrosion products Rys. 5. Analiza EDX produktów korozji

\section{Boiler vessel}

Bolier tubes OD 33,7x5 mm made of 10CrMo9-10 steel (see Table III) are concerned [7]. The tube broke after 8200 hs exposition at $575^{\circ} \mathrm{C}$ and $11 \mathrm{MPa}$ pressure (Fig. 6). As a fuel of the boiler was used a black oil (mazout).

Table III. Chemical composition [wt\%] Tablica III. Skład chemiczny [wag.\%]

\begin{tabular}{|c|c|c|c|c|c|c|c|c|c|c|}
\hline & C & $\mathrm{Mn}$ & Si & $P$ & $S$ & $\mathrm{Al}$ & $\mathrm{N}$ & $\mathrm{Cr}$ & $\mathrm{Cu}$ & Mo \\
\hline $\begin{array}{c}\text { Analysis } \\
\text { VúZ }\end{array}$ & 0,131 & 0,45 & 0,22 & 0,019 & 0,005 & 0,005 & - & 2,23 & 0,103 & 0,89 \\
\hline $\begin{array}{l}\text { 10CrMo9-10 } \\
\text { EN } 10028-2\end{array}$ & $\begin{array}{l}0,08 \\
0,14\end{array}$ & $\begin{array}{l}0,40 \\
0,80\end{array}$ & $\begin{array}{r}\text { ax. } \\
0,50\end{array}$ & $\begin{array}{r}\text { ax. } \\
0,020\end{array}$ & $\begin{array}{r}\text { ax. } \\
0,030\end{array}$ & - & $\begin{array}{l}\max \\
0,012\end{array}$ & $\begin{array}{l}2,00 \\
2,50\end{array}$ & $\begin{array}{l}\max . \\
0,30\end{array}$ & $\begin{array}{l}0,90 \\
1,10\end{array}$ \\
\hline
\end{tabular}




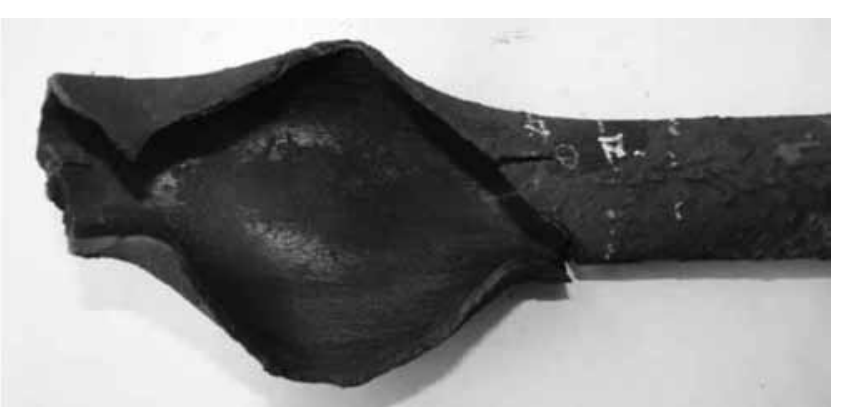

Fig. 6. Failure of the tube

Rys. 6. Awaria rurociągu

It is quite a common phenomenon in boilers burning black oil like mazout, that vanadium, sulfur and sodium compounds present in the combustion gases cause accelerated corrosion on fire side of boiler tubes. This phenomenon is called vanadium corrosion.

Above mentioned compounds usually form molten salts (fluxes). Fire side corrosion is observed at about $550{ }^{\circ} \mathrm{C}$.

Eutecticum temperature of $6 \mathrm{~V}_{2} \mathrm{O}_{5}-\mathrm{Na}_{2} \mathrm{SO}_{4}$ system is about $600{ }^{\circ} \mathrm{C}$, but some mixed oxides like $5 \mathrm{NaO}$ $-\mathrm{V}_{2} \mathrm{O}_{5}-10 \mathrm{~V}_{2} \mathrm{O}_{5}$ melts at $545^{\circ} \mathrm{C}[8]$. Molten salts at operation tem perature penetrate to the steel mostly intergranulary.

So the vanadium corrosion has features of LME. See a crack in Fig. 7 and 8 with EDX microanalysis in Table IV.

Table IV. Results of EDX microanalysis (wt\%)

Tablica IV. Wynik analizy EDX [wag.\%]

\begin{tabular}{|c|c|c|c|c|c|c|c|}
\hline & $\mathrm{S}$ & $\mathrm{Na}$ & $\mathrm{V}$ & $\mathrm{Fe}$ & $\mathrm{Cr}$ & $\mathrm{Mn}$ & $\mathrm{Si}$ \\
\hline 1 & 16,73 & 2,76 & 56,6 & 23,90 & - & - & - \\
\hline 2 & 2,67 & 0,43 & 28,08 & 67,87 & - & - & - \\
\hline 3 & - & - & 0,69 & 97,00 & 1,21 & 0,78 & 0,31 \\
\hline
\end{tabular}

\section{Conclusion}

The contribution dealt with case studies of failures in the high pressure gas pipeline, cement works and boiler, which were caused by liquid metal em-

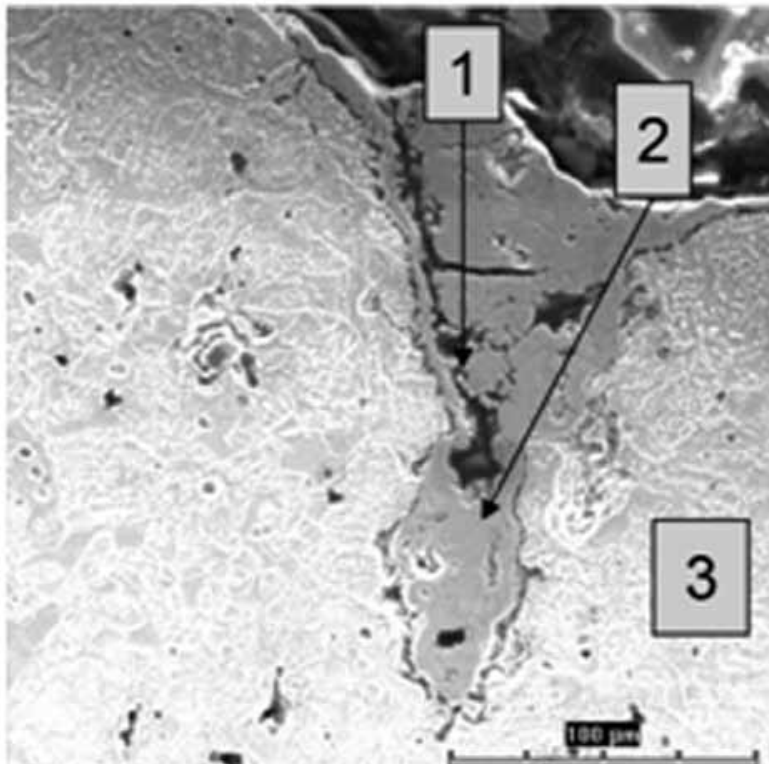

Fig. 8. Crack of vanadium corrosion

Rys. 8. Pęknięcie wywołane oddziaływaniem wanadu

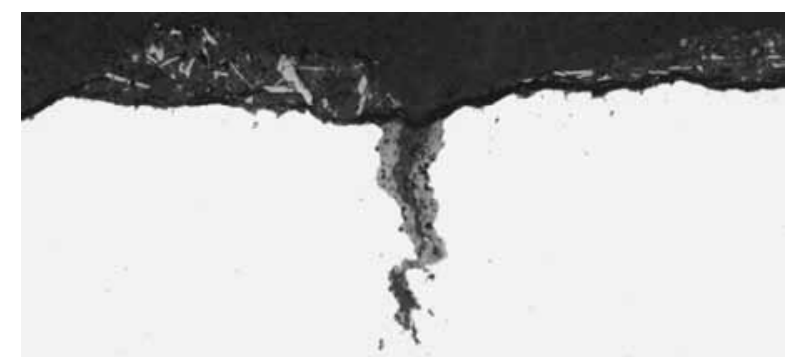

Fig. 7. Crack on fire side of tube

Rys. 7. Pęknięcie płomiennicy od strony paleniskowej

brittlement (LME). As a molten phase acted $\mathrm{Cu}$, low melting $\mathrm{Ni}_{3} \mathrm{~S}_{2}$ and $\mathrm{V}_{2} \mathrm{O}_{5}+\mathrm{Na}_{2} \mathrm{SO}_{4}$ eutecticum.

\section{References}

[1] D.G. Kolman.: Environmentally Induced Cracking, Liquid Metal Embrittlement, ASM Handbook, Volume 13A, Corrosion: Fundamentals, testing and Protection, ASM International, Materials Park, OH pp. 381-392 (2003).

[2] Liquid metal embrittlement, Metallurgical minutes, MAI, Summer 2004.

[3] TWI Technical knowledge, Great Abington, UK, 2000.

[4] D.G. Kolman.: Environmentally Induced Cracking, Solid Metal Embrittlement, ASM. Handbook, Volume 13A, Corrosion: Fundamentals, testing and Protection, ASM International, Materials Park, OH pp. 393 - 397 (2003).
[5] Bernasovský, P.-Brziak, P.: Case study of $15 \mathrm{G} 2 \mathrm{~S}$ grade gas pipeline. Technical. report, VÚZ-PI SR, ME 103, Bratislava, June 2003.

[6] Bernasovský, P.- Brziak, P.: Analysis of AISI 310 steel plate. Technical report, VÚZ-PI. SR, ME 148,Bratislava, 31.5.2007.

[7] Mráz, L'. et al.: Analysis of $33,7 \times 5 \mathrm{~mm}$ pipe made of $10 \mathrm{VrMo}$ 9-10 steel in boiler K3. Technical report, VÚZ - PI SR, ME 068, Bratislava, 13.4.2012.

[8] Andijani, J.-Malik, A.U.: Sulfur and vanadium induced hot corrosion of boiler tubes. Chemistry \& Industry Conference, Riyadh, Dec. 11-15, 2004. 